\title{
BREXIT, GÖÇ VE AVRUPA BÜTÜNLEŞME SÜRECI
}

\begin{abstract}
Ayselin YILDIZ*
Araştırma Makalesi

$\ddot{O} z$

Sinırların kontrolü söylemi üzerinden ulusal egemenliğe bir tehdit olarak gösterilen ve halkın endişelerini tetikleyerek siyasi amaçlar için araçsallaştırılan göç konusu, Birleşik Krallı'ın (BK) Avrupa Birliği'nden (AB) ayrılmasında en temel belirleyici unsurlardan biri olmuştur. BK, Avrupa Birliği’nin göç, sı̆̆ınma ve sınır yönetimi alanındaki politikalarının büyük ölçüde dışında kalmasına ve bu politika alanlarını kendi ulusal egemenliği kapsamında düzenlemesine ră̆men, Brexit süresince ülkedeki Avrupa-şüpheci partiler göçmen karşıtı popülist söylemleriyle göç konusunu daha da siyasallaştırmıştır. Brexit, Avrupa bütünleşme sürecinin geleceği için de kuramsal bağlamda incelenebilecek somut bir örnek teşkil etmektedir. Son dönemlerde daha sık tartışlmaya başlayan "farklılaştırılmış entegrasyon" kavramına özellikle göç politikalarına katılım bağlamında örnek gösterilebilecek BK, Brexit tecrübesiyle Birliğin geleceğinin "farkılaştırılmış dă̆llma” kavramı üzerinden yeniden tartışılabileceğini de göstermektedir.
\end{abstract}

Anahtar Kelimeler: Birleşik Krallık/Ingiltere, göç, Brexit, farklılaştırılmış entegrasyon

\section{Brexit, Migration and European Integration Process}

\begin{abstract}
Migration issue which has been framed as a threat to national sovereignty within the discourse of "getting back the controls of the borders" and which has also been instrumentalized for political purposes by triggering concerns among the public, constitutes one of the most distinctive factors of Brexit. Although United Kingdom (UK) opts out European Union's (EU) migration, asylum and border management policies to a great extent and keeps its sole national sovereignty in governing these areas, migration has been highly politicized by the Eurosceptic parties as part of their populist discourses during the Brexit process. Brexit also signifies a concrete case to be examined concerning the theoretical debates on the future of European integration.
\end{abstract}

* Doç. Dr., Yaşar Üniversitesi, ayselin.yildiz@ yasar.edu.tr ORCID: 0000-0001- 8845-2367 Makalenin Gönderilme Tarihi:10/3/2020 Kabul Edilme Tarihi: 15/9/2020 
Brexit experience demonstrates that while the country's participation to EU's migration policies can be explained through the highly popular current debate of "differentiated integration", it also opens a room for critically reconsidering the future of European integration through the new debate on "differentiated dissolution".

Keywords: United Kingdom, migration, Brexit, differentiated integration

\section{Giriş}

Birleşik Krallık (BK) ve Avrupa Birliği'nde (AB) büyük tartışma konusu olan Brexit sürecinin sona ermesiyle, 1973'de Avrupa Topluluğu'na katılan BK, 31 Ocak 2020 tarihinde AB'den resmen ayrılmıştır. Ayrılık sonrası birçok alanda nasıl bir düzenlenmeye gidileceği henüz netleşmese de, Brexit'in gerek BK gerekse de AB'de serbest dolaşım ve göç politikalarına ilişsin birçok etki yaratması beklenmektedir. Bu durum, Birleşik Krallık'ta yaşayan 3,5 milyondan fazla $A B$ vatandaşı ve $A B$ ülkelerinde yaşayan bir milyona yakın İngiliz vatandaşını doğrudan etkileyecektir. Kişilerin durumlarına ilişkin düzenlemeler her ne kadar $\mathrm{BK}$ ve $\mathrm{AB}$ arasında yürütülecek geçiş süreci müzakereleriyle belirlenecek olsa da, Brexit'in ve göç alanındaki düzenlemelerin $\mathrm{AB}$ bütünleşme süreci ve $\mathrm{AB}$ 'nin geleceğine ilişkin de belirleyici ve geniş bir etkisi olacağ 1 açıktır. Diğer bir ifadeyle, Brexit sürecinde artan siyasallaşma ve popülist söylemler çerçevesinde araçsallaşan göç konusu, hem Birleşik Krallık'ın Birlikten ayrılma sürecini tetikleyen en temel etkenlerden biri olmuş, hem de $\mathrm{AB}$ bütünleşme sürecinin geleceği tartışmalarında da önemli tehditlerden biri olarak öne çıkmaktadır.

Kuramsal çerçevede değerlendirildiğinde ise, farklılaştırılmış entegrasyon (differentiated integration) kavramının, BK'nın, $\mathrm{AB}$ göç, sığınma ve sınır yönetimini politikalarına ilişkin durumunu Birlik politikalarının dışında kalma imkanıyla (opt-out) ${ }^{1}$ açıklayabildiği, ancak bütünleşme sürecinin ilerlemesi ve sürdürülebilirliği için tercih edilen bu esnek bütünleşme modelinin diğer taraftan BK'nın Birlik’ten ayrılmasını da tetiklediği tartışılabilir. Dolayısıyla, Brexit örneği, göç politikalarının "optout"lar kapsamında $\mathrm{AB}$ bütünleşme sürecinin büyük oranda dışında tutulan alan olmasına rağmen, ulusal egemenliğe bir güvenlik tehdidi olarak nasil araçsallaştırılabileceğini ve $\mathrm{AB}$ bütünleşme sürecini nasıl tehdit edebileceğini göstermiştir. $\mathrm{Bu}$ bağlamda Brexit, $\mathrm{AB}$ 'nin bütünleşme sürecinin gelecekte

1 Opt-out, AB mevzuatı veya ortak politika alanlarından muaf tutulabilme durumudur. EurLex, https://eur-lex.europa.eu/summary/glossary/opting_out.html. Erişim Tarihi: Mart 2, 2020. 
nasıl bir modele evrileceği tartışmalarında da göç alanında Birlik düzeyindeki işbirliğinin belirleyici önemine dikkat çekmektedir.

Bu çalışmanın amacı, Brexit sürecinde göç konusunun Birleşik Krallık’ta nasıl siyasallaştırıldığını irdeleyerek Brexit sonrası $B K$ ve $A B$ vatandaşlarının serbest dolaşıma ilişkin olası durumlarını $\mathrm{AB}$ bütünleşme süreci çerçevesinde incelemektir. Çalışma, kuramsal olarak farklılaştırılmış entegrasyon modeli tartışmalarından hareketle, Birlik düzeyindeki bütünleşmeyi dinamik kılmak uğruna göç alanında sağlanan esnekliklerin ve opt-out imkanının, ulusal egemenlik ve bağımsızlık söylemleri kapsamında siyasallaşarak araçsallaştırılabildiğini, sonuç olarak da sürecin bütünleşme değil ayrılma ile sonuçlanabilmesini de etkilediğini tartışmaktadır.

Çalışma dört bölümden oluşmaktadır. İlk bölümde Brexit, farklılaştırılmış entegrasyon ve literatürde henüz yeni bir kavram olan "farklılaştırılmış dağılma" (differentiated disintegration) tartışmalarına örnek teşkil etmesi bağlamında kuramsal olarak değerlendirilmektedir. İkinci bölümde ise Birleşik Krallık'ın sınır yönetimi, göç ve sığınma politikalarına $\mathrm{AB}$ düzeyinde katılımı incelenmektedir. Üçüncü bölümde, göç konusunun Brexit sürecinde siyasi aktörlerce nasıl araçsallaştırıldığı irdelenmiştir. Çalışma, Brexit sonrası döneme ilişkin serbest dolaşımın İngiliz ve AB vatandaşları için nasıl düzenleneceğini ve BK'nın yeni "puan temelli göçmenlik sistemini” inceleyerek, sonuç bölümünde Brexit' in $\mathrm{AB}$ bütünleşme sürecine göç özelinde yarattığı etkiyi tartışmaktadır.

\section{Kuramsal Çerçeve: Farklılaştırılmış Entegrasyon ve Brexit}

AB'nin bütünleşme sürecinde yönetişim yetersizliklerden kaynaklanan ve dolayısıyla "kriz" olarak ifade edilen birçok konu, son dönemlerde farklılaştırılmış entegrasyon kavramı çerçevesinde daha fazla tartışılmaya başlanmıştır. Brexit süreci de, Avrupa'nın "Avro krizi”, "mülteci krizi”, "kimlik krizi" gibi son yıllarda artan çok katmanlı krizleri ${ }^{2}$ bağlamında farklılaştırılmış entegrasyon kavramı ekseninde değerlendirilen konulardan biridir. ${ }^{3}$ Farklılaştırılmış entegrasyon, içeresinde "çok vitesli", "değişken geometrili" ve "a la carte" gibi farklı birçok bütünleşme

2 Mustafa Kutlay, "Brexit Sonrası İngiltere ve AB Bütünleşmesinin Geleceği," Liberal Perspektif: Analiz 4, (Ocak 2017): 9.

3 Ebru Turhan, "Thinking out of The Accession Box: The Potential and Limitations of Internal and External Differentiated Integration between Turkey and the EU," CIFE Policy Paper 58, (2017):1-8. $\quad$ Erişim Tarihi: Mart 2, 2020. https://www.cife.eu/Ressources/FCK/files/publications/policy\%20paper/CIFE_Policy_Pap er_58_Thinking_out_of_The_Accession_Box_EU_Turkey_Ebru_Turhan_2017_1.pdf 
mekanizmalarını/stratejilerini barındıran, zaman, mekan ve konu bağlamında şekillenen şemsiye bir kavramdır. ${ }^{4}$ AB'nin mimarisi ve gelecekte nasıl bir yapıya dönüşebileceği konusu da son zamanlarda çok daha sıklıkla farklılaştırılmış entegrasyon tartışmaları ekseninde değerlendirilmektedir. "Esnek entegrasyon", "birlik içinde çeşitlilik" (unity in diversity), "merkez Avrupa" (core Europe), "tek merkezli iç içe geçen halklalar Avrupası" (Europe of concentric circles) gibi birçok kavram, farklılaştırılmış entegrasyon literatürü içinde tartışılmaktadır. ${ }^{5} \mathrm{AB}$ örneği bağlamında ise, farklılaştırılmış entegrasyon kavramı bazı üyelerin siyasi isteklilik, refah düzeyi, kimlik, ulusal anayasalarındaki düzenlemeler gibi farkl1lıklar nedeniyle diğerlerine göre daha farklı zaman, mekan ve düzeyde bütünleşmesi olarak tanımlanabilir. ${ }^{6}$

"Çok vitesli Avrupa" modeli, farklı yapısal özellikler ve siyasi isteklilik derecesine bağlı olarak kimi üye ülkelerin daha hızlı, kimi üyelerinse daha yavaş şekilde bütünleşme sürecine katılımını öngörür. Bütünleşmenin tüm üyelerce benimsenmesini nihai olarak hedefleyen bu monolitik modelde, temel değişken, sürece katılımı belirleyen "zaman"dır. Avrupa Parasal Birliği'nde, Avro bölgesine katılım için üyelere öngörülen geçiş süreci çok vitesli bütünleşme modeline örnek gösterilebilir. "Değişken geometrili Avrupa" modelinde ise nihai hedefte tek bir AB kurumsal mimari yapıs1 yoktur ve bu model farklı coğrafyalardaki üyelerin bütünleşme düzeylerinin de farklı olabileceğini öngörür. ${ }^{7}$ Schengen Anlaşmaları değişken geometrili

4 Alexander C-G Stubb, “A Categorization of Differentiated Integration." Journal of Common Market Studies 34, no 2 (1996): 283-295.

5 Christina J. Schneider, Conflict, Negotiation and European Union Enlargement. (Cambridge: Cambridge University Press, 2009); Kenneth Dyson ve Angelos Sepos, "Differentiation as a Design Principle and as a Tool in The Political Management of European Integration," içinde Which Europe? The Politics of Differentiated Integration, editörler Kenneth Dyson ve Angelos Sepos, (Basingstoke: Palgrave Macmillan, 2010); Dirk Leuffen, Berthold Rittberger ve Frank Schimmelfennig. Differentiated Integration. Explaining Variation in the European Union. (Basingstoke: Palgrave, 2013); Katharina Holzinger ve Frank Schimmelfennig, "Differentiated Integration in the European Union: Many Concepts, Sparse Theory, Few Data," Journal of European Public Policy 19, no 2 (2012): 292-305; Sandra Lavenex, "Concentric Circles of Flexible 'EUropean' Integration: A Typology of EU External Governance Relations," Comparative European Politics 9, no 4-5 (2011): 372-393; Benjamin Leruth ve Christopher Lord, "Differentiated Integration in the EU: a Concept, a Process, a System or a Theory?" Journal of European Public Policy 22, no 6 (2015): 754-763.

6 Frank Schimmelfennig, Dirk Leuffen ve Berthold Rittberger, "The European Union as a system of differentiated integration: interdependence, politicization and differentiation," Journal of European Public Policy, 22: no 6 (2015): 764-782.

7 Ziya Öniş ve Mustafa Kutlay, "Ekonomik Bütünleşme/Siyasal Parçalanmışlık Paradoksu: Avro Krizi ve Avrupa Birliği'nin Geleceği,” Uluslararası İlişkiler 9, no 33 (2012): 3-22. 
Avrupa modeline örnek verilebilir. A la carte Avrupa fikrinde ise yine monolitik olmayan esnek bir bütünleşme modeli öngörülürken, bu yapıda üyelerin konu/tema bağlamında farklı politika alanlarında uluslaraüstü $\mathrm{AB}$ yapılanmasını tercih edebilmesini veya sadece belirlenen politika alanlarına özgü bütünleşme sürecinin dışında kalmasını (opt-out) mümkün kılar. İngiltere ve Danimarka'nın gerek Avrupa Parasal Birliği'ne gerekse de $\mathrm{AB}$ göç ve iltica politikalarına ilişkin tam bütünleşmeye katılmamaları, a la carte Avrupa modeli kapsamında açıklanabilir. A la carte Avrupa modeli bütünleşme sürecinin geleceğine ilişkin tartışmalarda "çözülme", "dağılma" veya "AB'nin yeniden yapılanma ve reform" sürecinde doğabilecek sorun ve maliyetleri önlemede siyaseten en uygulanabilir çözümlerden biri olarak tartış1maktadır. Bu sayede, bütünleşmenin esnek bir yapıya kavuşturularak sürdürülebilir kılınması ve tematik temelde işbirliği üzerinden daha "yakın birlik" hedefine ilerlenmesi beklenmektedir.

Birleşik Krallık'ın, AB bütünleşme sürecindeki tarihsel tecrübesini açıklayan en uygun kuramsal çerçevenin farklılaştırılmış entegrasyon modeli olduğu söylenebilir. Farklılaştırılmış veya esnek bütünleşme kavramları her ne kadar bütünleşmenin geleceği için faydalı ve tercih edilmesi gereken bir mekanizma olarak ele alınsa $\mathrm{da}^{8}$, bu kavrama ilk eleştirileri yönelten Walker sürecin risklerini "artan parçalanmışlık, belirsizliğin meşrulaşması, demokrasinin azalması ve siyasi başarısızlık" olarak belirtmiştir. ${ }^{9}$ Koening de farklılaşmanın heterojen bir yapıyı teşvik ederek, halihazırda kırılgan Avrupa kimliği duygusunu zayıflattığını ve hatta dağılmayı tetikleyici eğilimlere neden olabileceğini vurgulamıştır. ${ }^{10}$ Üye devletlerin AB'nin ortak politikalarına katılmak istememelerinden kaynaklı yaşanabilecek bütünleşme krizlerine bir çözüm alternatifi olarak görülen farklılaştırılmış entegrasyon modeli, Brexit örneğinde ise bütünleşmeyi değil Birlik’ten ayrılmayı getirmiştir. Farklılaştırılmış entegrasyon tecrübesi umulduğu gibi BK'yı merkezcil bir eğilime teşvik ederek AB'ye yakınlaştırmak veya politikalarda derinleşme yerine, Avrupa Birliği Antlaşması 50.maddenin gerçekleşmesiyle "farklılaştırılmış dağılma" kavramı için dönüm noktası niteliğinde bir örnek olmuştur. ${ }^{11}$ Farklılaştırılmış dağılma, "bir üye devletin, Avrupa bütünleşme

8 Hellen Wallace, Flexibility: A Tool of Integration or a Restraint on Disintegration?. (Oxford: Oxford University Press, 2000).

9 Neil Walker, "Sovereignty and Differentiated Integration in the European Union," European Law Journal 4, no 4 (1998): 387.

${ }^{10}$ Nicole Koenig, "A Differentiated View of Differentiated Integration," Jacques Delors Institute Policy Papers 140, (23 July 2015). Erişim Tarihi: Mart 2, 2020. https://institutdelors.eu/en/publications/a-differentiated-view-of-differentiated-integration/

${ }^{11}$ Benjamin Leruth, Stefan Ganzle ve Jarle Trondal, "Differentiated Integration and Disintegration in the EU After Brexit: Risks versus Opportunities," Journal of Common Market Studies 57, no 6 (2019): 1386 
sürecine katılımdan çekilmesi veya $\mathrm{AB}$ politikalarının üye devletlere geri transfer edildiği genel bir stratejiler durumu" olarak tanımlanabilir. ${ }^{12}$

Benzer şekilde, Schimelfennig de Brexit sürecini post-işlevselci bir yaklaşım çerçevesinde literatürde oldukça yeni bir tartışma olan "farklılaştırılmış dağılma" kavramı ile açıklamaktadır. ${ }^{13}$ Brexit, Hooghe ve Marks tarafından tartışılan ve farklılaştırılmış dağılmayı tetikleyen üç temel etkeni de somut olarak içinde barındıran bir örnek olmuştur: i) bütünleşme sürecinin "kimlik" mantığına ilişkin siyasi alanlarda yayılma etkisi, ii) Avrupa şüpheci popülist sağ partilerin yükselişi iii) bütünleşme sürecine ilişkin referandumların varlığ ${ }^{14}$ Makalenin üçüncü bölümünde bu üç etkenin Brexit süreci özelinde özellikle göç konusu üzerinden nasıl gerçekleştiğine değinilmektedir. Dolayısıyla, BK'nın geçmişten bugüne AB'den aldığı birçok imtiyaz, özel durum ve opt-out durumuna ${ }^{15}$ rağmen Brexit' in gerçekleşmesi, opt-out imkanına müsaade etmenin Avrupa bütünleşme sürecini kolaylaştırıcı ve destekleyici bir etken olmadığını da göstermektedir. ${ }^{16}$

\section{Birleşik Krallık'ın Sınır Yönetimi, Sığınma ve Göç Alanlarında} AB Bütünleşme Sürecine Katılımı

Avrupa Topluluğu'na 1973'te üye olan ve 47 y1l sonra Birlik'ten ayrılan Birleşik Krallık, AB kurucu antlaşmalarına ilişsin imzaladığg Protokoller sayesinde belirli alanlarda diğer üyelere göre resmi olarak ayrıcalıklı ve "özel bir statü”ye sahipti. Bu özel statü kapsamında BK, Avro alanı, AB içinde serbest dolaşıma izin veren Schengen Anlaşması ve ilgili düzenlemeleri, $A B$ özgürlük, güvenlik ve adalet alanı gibi $\mathrm{AB}$ üyeleri için bağlayıcı olan birçok düzenleme ve politikanın dışında kalarak ayrıcalıklı durumunu üyelikten çıkana kadar sürdürmüştür. Schimmelfennig'in, ülkelerin yüksek refah düzeyinin $\mathrm{AB}$ ile daha derin bir bütünleşmeyi reddedebilmeyi göze almasında

12 Leuffen vd., 2013

${ }^{13}$ Frank Schimmelfennig, "Brexit: differentiated disintegration in the European Union." Journal of European Public Policy 25, no 8, (2018): 1154-1173.

${ }^{14}$ Leisbet Hooghe ve Gary Marks, "A Postfunctionalist Theory of European Integration: From Permissive Consensus to Constraining Dissensus," British Journal of Political Science 39, (2009): 1-23.

15 Duttle, Thomas, Katharina Holzinger, Thomas Malang, Thomas Schaubli, Frank Schimmelfennig ve Thomas Winzen. "Opting out from EU Legislation: The Differentiation of Secondary Law.” Journal of European Public Policy 24, no 3 (2017): 406-428. Erişim Tarihi: Mart 2, 2020.

${ }^{16}$ Holzinger, Katharina ve Tosun, Jale. "Why Differentiated Integration Is Such A Common Practice In Europe: A Rational Explanation.” Journal of Theoretical Politics 31, no 4 (2019): 643. 
önemli bir etken olduğu tespiti, ${ }^{17} \mathrm{BK}$ 'nın $\mathrm{AB}$ bütünleşme süreci tarihi için de geçerlidir. Ulusal egemenliği pekiştirme bağlamında, ayrıca AB'ye karşı sahip olduğu güçlü kurumsal pazarlık gücüyle elde ettiği bu ayrıcalıklar, Birleşik Krallık'ın üyeliği süresince AB'nin "daha fazla siyasi birlik" hedefinin dışında kalmak istemesi yönündeki tercihini de göstermektedir.

Birleşik Krallık, AB üyeliği süresince göç, sığınma ve sınır yönetimi politikaları özelinde yetkilerini tam olarak $\mathrm{AB}$ düzeyine devretmeyerek, ulusal egemenliğini bu alanlarda kullanmaya devam etmiştir. Diğer bir ifadeyle, $\mathrm{AB}$ ile derinleşmeye gitmek yerine hükümetlerarası işbirliğine dayalı bir yaklaşım kapsamında göç politikalarını belirlemeyi ve uygulamayı tercih etmiştir. BK'nın göç alanında $A B$ bütünleşme sürecine katılımı, i) sınır yönetimi politikalarına ve Schengen sistemine katılım, ii) Avrupa Ortak Sı ̆̆ınma Sistemi’ne katılım, iii) AB üyesi olmayan üçüncü ülke vatandaşlarına yönelik Avrupa ortak göç politikasına katılım olmak üzere üç temel başlık altında incelenebilir. Bu alanlarda BK, tamamen bütünleşme sürecinin dışında kalmamış, seçtiği kısıtlı alanlarda AB ile uyumu (opt-in) tercih ederken, büyük ölçüde ise opt-out imkânı ile sürecinin dışında kalmayı tercih etmiştir.

Birleşik Krallık, AB ortak pazarını en güçlü şekilde destekleyen, katılım gösteren ve ortak pazardan en etkin şekilde faydalanan üyelerden biri olmasına rağmen, ${ }^{18}$ ortak pazarın dört temel serbestisinden biri olan kişilerin serbest dolaşımı konusunu özel statüsüne bağlı olarak kendi ulusal yetki alanında düzenlemekteydi. Amsterdam Antlaşması, AB içinde serbest dolaşıma izin veren Schengen sistemini $A B$ mimarisine tamamen dahil ettiğinde ve "Avrupa Özgürlük, Güvenlik ve Adalet Alanı"nı oluşturduğunda, BK büyük ölçüde bunun dışında kalmış, sınır kontrolleri ve vize politikası konusunda otonom yetkilerini korumuştur. BK, ortak pazarın en temel belgesi olan serbest dolaşıma ilişkin AB'nin 2004/38 sayılı Vatandaş Hakları Direktifini uygulasa da, BK'nın kendi vize politikasını sürdürmesi ve hatta Fransa'da ve Belçika'daki vize kontrol noktalarıyla sınırlarına girişi düzenlemesi, ortak pazarın etkin işleyişine kısıtlayıcı girişimler olarak da değerlendirilebilir. BK, serbest dolaşım ve vize konularında Schengen'e katılmamasına rağmen, AB'nin sınır güvenliği ajans1 olan FRONTEX'in birçok sınır operasyonlarına katılmıştır. ${ }^{19}$ Bunun yanı sıra, İngiltere

17 Frank Schimmelfennig, "Good governance and differentiated integration. Graded membership in the European Union," European Journal of Political Research 55, no 4 (2016): 795.

${ }^{18}$ Birleşik Krallık Hükümeti, Review of the Balance of Competences between the UK and the EU: The Single Market (Londra, Temmuz 2013), Erişim Tarihi: Mart 3, 2020, https://assets.publishing.service.gov.uk/government/uploads/system/uploads/attachment_d ata/file/227069/2901084_SingleMarket_acc.pdf.

19 İngiltere, Frontex yönetim kurulunda gözlemci statüsündedir ancak Frontex'in Ege ve Akdeniz'de yürüttüğü briçok sınır yönetim operasyonuna katılım göstermiştir. Bunlardan 
biyometrik pasaportlardaki $\mathrm{AB}$ güvenlik önlemleri ve kolluk kuvvetlerinin $\mathrm{AB}$ Vize Bilgi Sistemi'ne erişimi gibi Schengen'in güvenlik boyutundaki konularına katılım göstermiştir. ${ }^{20}$

Sığınma (iltica) konuları ise, $\mathrm{AB}$ düzeyinde hükümetlerarası işbirliği yaklaşımı kapsamında çoğunlukla ülkelerin kendi egemenlik alanlarında düzenlenmiş ve uluslarüstüleşme süreci oldukça yavaş ilerleyen bir alandır. Sığınma politikalarının kısmen de olsa $\mathrm{AB}$ düzeyinde ortak politika alanına taşınabilmesi ancak Amsterdam Anlaşması sonrası dönemde sınırlı adımlarla başlatılabilmiştir. BK, 2000 ve 2006 arasında gerçekleşen ve Amsterdam sonrası "ilk dönem" olarak adlandırılan sürece katılmıştır. ${ }^{21} \mathrm{Bu}$ süreç, Geçici Koruma Direktifi (2001/55/EC), Dublin II Tüzüğü (2003/343), Eurodac Tüzüğü (2000/2725), Siğınma Talepleri Prosedürleri Direktifi (2005/85) ve Kabul Koşulları Direktifi (2003/9) gibi daha çok mevzuata yönelik ve asgari standartları belirleyen, temelde uygulamanın yine devletlerin iradelerine bırakıldığ 1 düzenlemeleri kapsamaktadır. BK, "ikinci aşama" olan Avrupa Ortak Sığınma Sistemi'nin geliştirildiği, asgari standartların belirlenmesinde üyeler arası uyumun hedeflendiği sürece ise katılmayacağını beyan etmiştir. Bu bağlamda, güncellenen Kabul Koşulları Direktifi (2013/33) ve Sığınma Talepleri Prosedürleri Direktifi'nin (2013/32) dışında kalmıştır. Ancak, yine güvenlik ve geri gönderme odaklı bir yaklaşımla, BK, AB'nin üçüncü ülkelerle imzaladığı geri kabul anlaşmalarına, 2013 Dublin III Tüzügüne (2013/604), sı ğınmacıların ve düzensiz göçmenlerin parmak izlerinin alınarak kayıt altında tutulduğu EURODAC (Avrupa Siğınma Daktiloskopi Veritabanı) kullanımına ve üye devletlerin veya Europol'un talebiyle bu verilerin paylaşılmasını sağlayan EURODAC Tüzüğüne (2013/603) katılım göstermektedir. ${ }^{22}$ Elbette ki, Brexit' in geçiş döneminin sonlamasıyla, şu anda BK'nın bu alanlardaki katılım ve faydalanma durumu yeniden düzenlenecektir.

bazıları; Türkiye-Yunanistan ve Türkiye-Bulgaristan kara sınırlarındaki düzensiz göçü önlemeye yönelik Poseidon Kara Operasyonu; Ege Denizi'nde Türkiye-Yunanistan arasındaki düzensiz göçü engellemeye yönelik Poseidon Deniz Operasyonu; Cezayir ve Fas'tan İspanya'ya yönelen düzensiz göçe ilişkin düzenlenen Indalo Operasyonu; İtalya'ya yönelen düzensiz göçü engellemeye yönelik Hermes Operasyonu ve Aeneas Operasyonu olarak siralanabilir.

${ }^{20}$ Cathryn Costello ve Emily Hancox, The UK, EU Citizenship and Free Movement of Persons. (UK: University of Oxford, 2014). Erişim Tarihi: Mart 2, 2020, https://migrationobservatory.ox.ac.uk/wp-content/uploads/2016/04/PolicyPrimerUK_EU_Asylum_Law.pdf.

${ }^{21}$ Birleşik Krallık Parlementosu Lordlar Kamarası AB Komitesi, "Brexit: Refugee Protection and Asylum Policy", 48th Report of Session 2017-2019, Ekim 11, 2019. Erişim Tarihi: Mart 2, 2020. https://publications.parliament.uk/pa/ld201719/ldselect/ldeucom/428/428.pdf.

22 Avrupa Komisyonu, "EURODAC 2020," Erişim Tarihi: Mart 2, 2020, https://ec.europa.eu/knowledge4policy/dataset/ds00008_en 
Birleşik Krallık, AB üyesi olmayan üçüncü ülke vatandaşlarına (third country nationals) yönelik AB'nin ortak göç politikası ve uygulamaların da yine opt-out imkanını kullanarak katılım göstermemektedir. BK'nın katılım göstermediği mevzuat ve uygulamalara, nitelikli işçi göçüne yönelik çıkartılan Mavi Kart Direktifi (2009/50/EC), Aile Birleşimi Direktifi (2003/86/EC), Geri Gönderme Direktifi (2008/115/EC) ve Uzun Dönemli Oturum İzni Direktifi (2003/109/EC) örnek gösterilebilir. Dönemin BK Başbakanı Theresa May'in, 2018'deki bir konuşmasında, “íki sene önce İngiliz halkı sınırlarının kontrolünü geri almayı ve $A B$ 'den ayrılmayı oyladı. İlk kez, ülkeye kimin geleceğini kontrol edebilen ve kimin geleceğini seçebilen ülke, bu ülke olacak" ${ }^{23}$ şeklindeki ifadesinde üçüncü ülke vatandaşlarına yönelik olarak BK'nın zaten tam egemenlik yetkisine sahip olduğunu unutmamak gerekir. ${ }^{24}$ Brexit sürecinin en önemli etkilerinden biri, geçiş dönemi tamamlandığında $\mathrm{BK}$ vatandaşlarının $\mathrm{AB}$ için üçüncü ülke vatandaş1 statüsünde değerlendirilebilecekleri ve yukarda belirtilen mevzuata tabi olmaları durumunda ortaya çıkacaktır.

Özetle, Birleşik Krallık’ın AB'nin göç politikalarına bütünleşme süreci kapsamında katılımı genel olarak değerlendirildiğinde, göçmenlerin Avrupa'ya erişimlerini kısıtlayıcı önlemler veya göçün güvenlikleştirilmesi söz konusu olduğunda BK'nın Birlik politikalarına katılım gösterdiği görülmektedir. Ancak sınır yönetimi, sığınma, mültecilerin kabulü, aile birleşimi, göçmen ve üçüncü ülke vatandaşlarının hakları söz konusu olduğunda, BK'nın AB politikalarının dışında kalmayı seçerek bu alanları kendi ulusal politikalarıyla düzenleme eğiliminde olduğu görülmektedir.

\section{Brexit Sürecinde Göçün Siyasallaşması}

Birleşik Krallık'ın 1980'lerde ekonomik ve siyasi nedenlerle göçmenlere kapılarını açması sonrasında bugün BK'da göçmen nesillerle şekillenmiş etnik, kültürel ve dini farklılıkları bir arada barındıran çok kültürlü bir toplumsal yapı bulunmaktadır. 65 milyon toplam nüfusu olan BK'da 3,7 milyon $A B$ vatandaşı ve 2,7 milyon da $A B$ vatandaşı olmayan üçüncü ülke vatandaşı yaşamaktadır. ${ }^{25}$ Ülkede yaşayan yabancı uyruklu nüfusa

${ }^{23}$ Tom McTague, "Theresa May Reveals new UK Immigration System," Politico, Ekim 2, 2018, Erişim Tarihi: Mart 2, 2020 www.politico.eu/article/theresa-may-unveils-new-ukimmigration-system

24 Joe Owen, Maddy Thimont Jack, Adela Lacobov ve Elliot Christensen, "Managing Migration After Brexit," Institute for Government, (Mart 2019), Erişim Tarihi: Mart 2, 2020, https://www.instituteforgovernment.org.uk/sites/default/files/publications/IfG-MigrationAfter-Brexit_4.pdf

${ }^{25}$ BK Ulusal İstatistik Ofisi (Office for National Statistics/ONS), "Migration Statistics Quarterly Report: February 2020," Erişim Tarihi: Mart 2, 2020, 
bakıldığında ise 902,000 kişi ile Polonya ilk sırada, 457,000 kişi ile Romanya ikinci ve 351,000 kişi ile Pakistan üçüncü sırada yer almaktadır. ${ }^{26}$

Brexit süreci öncesinde, BK kamuoyunda çok kültürlü yapıya tepkili ve ülkenin değişen değerlerinden hoşnutsuz vatandaşların temel endişelerinin başında, BK' daki yabancı sayısının artması ve ulusal kimliğe bağlı değişimler olduğu görülmektedir. Bu endişeler, 2016'da yaklaşık bir milyon göçmen ve mültecinin $\mathrm{AB}$ ülkelerine erişimi ve $\mathrm{AB}$ 'nin bu insani durumu yönetememesinden kaynaklı "mülteci krizi"nin yaşanmasıyla daha da artmıştır. Brexit oylamasının hemen öncesinde, Mayıs 2016'da yapılan Avrobarometre anketine göre, BK vatandaşları ülkeleri için en önemli konunun göç (\%38) olduğunu belirtmişlerdir. ${ }^{27}$ Sıralamada göç konusunu sağl1k ve sosyal güvenlik (\%26) ve terör (\%23) konuları takip etmektedir. Aynı ankette BK vatandaşları AB'nin en önemli konusunu ise \%51 oranla yine göç olarak belirtmişlerdir. Göçmenleri ekonomik, kültürel ve bir güvenlik tehdidi olarak gösteren Brexit yanlıları da (Vote Leave), kampanyalarını göçü 1sıtlamak için ülkenin egemenliğinin ve sınır kontrollerinin AB'den geri alması yönünde bir söylem üzerinden yürütmüştür. ${ }^{28}$

Göç konusunun siyasallaştığ ilk örneklerden biri 2013'te dönemin BK Başbakanı David Cameron'un, BK'nın AB içindeki özel statüsünü AB ile yeniden müzakere edeceğini ve 2015 ulusal seçimleri sonrasında tek başına iktidara gelmesi durumunda ülkenin $\mathrm{AB}$ üyeliğini referanduma sunacağını ifade ettiği riskli süreçte ortaya çıkmıştır. Ancak Başbakan David Cameron'un, $\mathrm{AB}$ üyesi devletlerle yürüttüğü zorlu müzakereler sonucunda, 19 Şubat 2016'da elde ettiği ülkenin özel statüsü ve ayrıcalıklar, ne Avrupa şüpheci Muhafazakarları memnun edebilmiş ne de BK vatandaşlarının Birlikten ayrılma kararını önlemek için yeterli olmuştur. BK, sınır yönetimi, sığınma ve göçe ilişkin politikalarda opt-out imkânı ile Birlik uygulamalarının büyük ölçüde dışında kalmayı sürdürmek istemiş, müzakerelerde göç konusu en belirleyici unsurlardan biri olarak öne çıkmıştır. Örneğin, BK'a gelen göçmenlerin ülkeye girişlerinden ancak dört yıl sonra bazı sosyal yardımlardan yararlanabilmesini öngören "emniyet/acil durum freni sistemi",

https://www.ons.gov.uk/peoplepopulationandcommunity/populationandmigration/internationa lmigration/bulletins/migrationstatisticsquarterlyreport/february2020

${ }^{26}$ BK Ulusal İstatistik Ofisi, 2020

27 Avrupa Komisyonu, "Standard Eurobarometer 85," (Mayis 2016) https://ec.europa.eu/commfrontoffice/publicopinionmobile/index.cfm/Survey/getSurveyDe tail/surveyKy/2130

${ }^{28}$ Harold D. Clarke, Matthew Goodwin, Paul Whiteley, "Why Britain Voted for Brexit: An Individual-Level Analysis of the 2016 Referendum Vote," Parliamentary Affairs 70, 3 (Temmuz 2017): 439-464. 
göçmenler için işsizlik yardımı, göçmen işçilerin çocukları için aldıkları devlet yardımlarını kendi uilkelerine transfer edebilmeleri, aile birleşimi kısıtlamaları ve serbest dolaşımın geleceğine dair konular müzakerelerin en önemli ve en çok tartışılan konuları olmuştur. ${ }^{29}$

Brexit kampanya sürecinde ise, ülkenin $\mathrm{AB}$ 'den ayrılması gerektiğini savunan Birleşik Krallık Bağımsızlık Partisi (UKIP) Başkanı Nigel Farage, Muhafazakâr Parti'nin bazı üyeleri ve dönemin Londra Belediye Başkanı Boris Johnson tarafindan göç konusu siyasi amaçlar doğrultusunda etkili şekilde ön plana çıkarılmış ve araçsallaştırılmıştır. Ayrılma yanlıları tarafından, "Bağımsız ve güvenli Britanya" sloganının arkasında, AB üyeliğinin BK'ya göçmen akınına neden olduğu, BK'ya çalışmak için gelen göçmenlerin hem işsizliği arttırdığı hem de sosyal güvenlik sistemine yük olduğu yönünde bir referandum kampanyası yürütülmüştür. ${ }^{30}$ Kampanyasını “İngiliz olmak, İngiliz değerlerini korumak ve çok kültürlü yapıya karş1 çıkmak" olarak belirleyen UKIP, kamuoyunda göçmenlerin toplumsal ve ekonomik olarak olumsuz etkiler yarattığı şeklindeki endişeleri ve korkuları tetiklemiştir. Referandum sonuçlarına bakıldığında da ayrılma yönünde oy kullanan bölgelerin İngilizlerin yoğun olarak yaşadıkları bölgeler olduğu görülmektedir. Örneğin, referandumda \%58 ile AB'den ayrılma yönünde en yüksek oyu veren bölgelerden biri olan Kuzey Doğu İngiltere'de, 2019 itibariyle nüfusun \%97'si İngiliz vatandaşıdır. ${ }^{31}$

Brexit kampanyasında 2016'da, Suriye iç savaşıly tetiklenen ve Avrupa'ya yönelen yaklaşık bir milyon göçmen ve sığınmacının Avrupa ülkelerine ulaştığı ve mülteci krizi olarak nitelendirilen dönemin de göçün araçsallaştırılmasında etkisi olmuştur. Oysa ki BK'nın AB sığınma politikalarının çok büyük ölçüde dışında kalmasına da bağlı olarak, 2016'da aldığı sığınma başvurusu sadece 39,355'dir. ${ }^{32}$ Aynı dönemde Almanya'nın

29 Gülsüm Alan, “AB'den İngiltere'ye Özel Statü,”, Euronews, Şubat 20, 2016, https://tr.euronews.com/2016/02/20/ab-den-ingiltereye-ozel-statu.

${ }^{30}$ Akses, Selen, Emre Ataç, Ahmet Ceran, Sema Çapanoğlu, Çisel İleri, İlge Kıvılcım, Çiğdem Nas, Deniz Servantie ve Yeliz Şahin, Britanya Referandumu ve Sonrast: AB Entegrasyon Sürecinin Geleceği ve Türkiye. (İstanbul: İktisadi Kalkınma Vakfı Yayınları, 2016), Erişim Tarihi: Mart, 2, 2020 https://www.ikv.org.tr/images/files/IKV_Brexit_Yayin\%20no\%20284(1).pdf

${ }^{31}$ BK Ulusal İstatistik Ofisi (ONS), "The Electoral Commission, EU Referendum Results by Region: North East," https://www.electoralcommission.org.uk/who-we-are-and-what-wedo/elections-and-referendums/past-elections-and-referendums/eu-referendum/results-andturnout-eu-referendum/eu-referendum-results-region-north-east; BK Ulusal İstatistik Ofisi, 2020.

32 Eurostat, "Asylum and first time asylum applicants by citizenship, age and sex," Erişim Tarihi: Mart 2, 2020, http://appsso.eurostat.ec.europa.eu/nui/setupDownloads.do. 
aldığ 1 başvuru sayısı ise BK'nın yaklaşık 18 katı olarak 722,365 'tir. ${ }^{33}$ Dönemin UKIP Partisi lideri Nigel Farage, referandum öncesi bir konuşmasında düşmanın nerede olduğunu Avrupa'nın göçmenlere açık kapı politikasının uygulamasıyla ilişkilendirmiş, hem göçün İngiliz halkının günlük yaşamında yarattığı olumsuz etkilerin, hem de Batı'nın karşılaştığı yeni terör ve güvenlik tehditlerinin $\mathrm{AB}$ sınır politikalarından kaynaklandığını ifade etmiştir. ${ }^{34}$ Yine Farage, Brexit kampanyasında "Eğer AB'de kalmayı tercih ederseniz, İran, Irak ve Suriye ile komşu ve yoksul bir ülke olan Türkiye ile aynı birlik içerisinde yer almayı seçmiş olacaksınız. 75 milyon nüfusu olan bir ülkeye serbest dolaşım hakkını vermiş olacaksınız. AB'den ayrılma kararı almak ve sınırlarımızın kontrolünü geri almak bizim için daha güvenli"35 şeklinde açıklamalarıyla popülist söylemler üzerinden kamuoyunda asılsız endişe ve korkuları tetiklemiştir. UKIP ulusal kimlik unsurunu ön plana çıkararak, göçün olumsuz etkileri algısı üzerinden kamuoyunda yarattığ1 endişeyle kampanyasına desteği arttırmıştır. ${ }^{36}$

$A B$ ve göçmen karşıtı UKIP, $A B$ bütünleşmesinin göç alanında İngiltere üzerinde yaratacağı olumsuz etkiler söylemini referandum kampanyasında gerçeklikten uzak biçimde kullanarak seçmenin 23 Haziran 2016'daki referandumda yüzde \%51,9 ile $\mathrm{AB}$ 'den ayrılma kararında oldukça etkili olmuştur. Kamuoyu yoklamalarının da gösterdiği gibi UKIP'in aldığ 1 destekte, partinin $\mathrm{AB}$ karşıtlığından çok göç konusunda endişeleri arttırması daha etkili olmuştur. ${ }^{37}$ UKIP destekçilerinin \%70'i göç konusunu BK'ın en önemli sorunu olarak belirtmiştir. ${ }^{38}$ Benzer bir diğer çalışma, Brexit sürecinde ayrılıma yanlılarının kararlarında en etkili unsur olarak göçmenlerin kamu hizmetlerinin kullanımı ve ekonomiye yük olmaları şeklindeki endişelerini belirtmektedir. ${ }^{39}$ Dennison ve Geddes, 2000'lerden beri, BK'daki ulusal tartışmalarda Avrupa şüpheciliğin bir yan konu durumuna geldiğini ancak

33 ibid

${ }^{34}$ BBC News, "EU Referendum: Nigel Farage Tells Leave Campaigners to Focus on Migration,” Nisan 29, 2016, Erişim Tarihi: Mart 2, 2020. https://www.bbc.com/news/ukpolitics-eu-referendum-36167329.

35 RT, “Turkey's Bid for EU Membership Bolsters Case for Brexit- Farage,” Mart 9, 2016, Erişim Tarihi: Mart 2, 2020. https://www.rt.com/uk/335012-turkey-eu-membership-farage/

${ }^{36}$ Matthew Goodwin ve Caitlin Milazzo, UKIP: Inside the Campaign to Redraw the Map of British Politics. (Oxford: Oxford University Press, 2015); Clarke vd., 2017.

${ }^{37}$ Kutlay, 10.

38 Will Somerville, "Brexit: The Role of Migration in the Upcoming EU Referendum," Migration Policy Institute, Mayss 4, 2016, Erişim Tarihi: Mart 2, 2020 https://www.migrationpolicy.org/article/brexit-role-migration-upcoming-eu-referendum.

39 Alisa Henderson, Charlie Jeffery, Dan Wincott ve Richard Wyn Jones, "How Brexit was Made in England," The British Journal of Politics and International Relations 19, no 4 (2017): 631-646. 
Brexit örneğinde de görülebileceği gibi göçün temel mesele olarak öne çıktığını vurgulamaktadır. ${ }^{40}$

Hooghe ve Marks'in belirttiği gibi, AB bütünleşme sürecine ilişkin farklılaştırılmış dağılmayı etkileyen üç temel etken ${ }^{41}$ Brexit sürecinde göç konusu bağlamında somut olarak gerçekleşmiştir. Göç; i) ulusal kimliğe ve kimliğe ilişkin değerlere bir tehdit olarak, ii) Avrupa-şüpheci popülist UKİP tarafından iii), referandum sürecinin de varlığı ile $\mathrm{BK}$ 'nın $\mathrm{AB}$ üyeliğinden ayrılması için kullanılmıştır. Bu noktada, referandumun varlığı da, 2000'lerde işgücü piyasası ve işverenlerin çıkarları doğrultusunda elitler tarafindan geliştirilen göç politikalarının, 2016'daki Brexit referandumu ile geniş bir halk kitlesinin kararı ile belirlenebilmesine evrilen süreçte önemli bir dönüm noktasidır. ${ }^{42}$

Diğer yandan, Brexit ilk kez bir $\mathrm{AB}$ üyesinin referandumdan çıkan "hayır" yanıtı ile farklılaştırılmış entegrasyon yerine Birlik'ten tamamen ayrılmanın tercih edildiği bir örnek de olmuştur. ${ }^{43}$ Brexit, tıpk1 "Avro krizi" ve "mülteci krizi" gibi Avrupa'da halkların gözünde AB'nin siyasi meşruiyetini zedeleyebilecek bir konu haline gelmiş ${ }^{44}$ ve Avrupa çapında ayrılma yanlısı diğer siyasi grupları da tetiklemiş̧ir. Aşırı sağcı Danimarka Halk Partisi, "Danimarka halkının özgürlüğü ve kültürel mirasını korumak" söylemi üzerinden mülteci ve göçmenleri Danimarka'nın toprak bütünlüğüne bir tehdit olarak göstererek, Danimarka'nın AB'den ayrılması gerektiğini savunmaktadır. Benzer söylemler, İsveç'te Demokratlar Partisi, İtalya'daki AB karşııı Beş Yıldız Hareketi, Fransa'da Ulusal Cephe Partisi tarafından da kullanılmıştır ve bu gelişmeler Avrupa'daki ayrılma ve parçalanma endişelerini etkilemektedir.

\section{Brexit Sonrası Süreç: Serbest Dolaşım Hakkından Göçmenliğe}

$A B$ ve $B K$ arasındaki geçiş süreci 31 Aralık 2020'de tamamlandığında, $\mathrm{AB}$ bütünleşme sürecinin ve ortak pazarın en temel öğelerinden biri olan serbest dolaşım hakkı da tüm $\mathrm{AB}$ ve $\mathrm{BK}$ vatandaşları için sonlanacaktır. Diğer

40 James Dennison ve Andrew Geddes, "Brexit and the Perils of Europeanised Migration," Journal of European Public Policy 25, 8 (2018), 1144.

${ }^{41}$ Hooghe ve Marks, 2009

42 Dennison ve Thierry, 2018.

43 Thierry Chopin ve Christian Lequesne, "Differentiation as a Double-Edged Sword: Member States' Practices and Brexit," International Affairs 92, 3 (2016): 531-545.

44 Cornelius Cappelen ve Yvette Peters, "Diversity and Welfare State Legitimacy in Europe: The Challenge of Intra-EU Migration," Journal of European Public Policy 25, 9 (2018): $1336-1356$. 
bir ifadeyle, hem $B K$ 'de hem de $A B$ 'de kişilerin işgücü piyasasına erişimi yeni bir mevzuat kapsamında düzenlenecektir. Bu durum, Avrupa ekonomik bütünleşme sürecinin en temel unsuru olan Ortak Pazar ve dört özgürlük anlayışının BK özelinde parçalanması anlamına gelmektedir. Oysa ki, BK, 2004'teki AB genişlemesi sonrasında üye ülkelere tanınan ilk yedi senelik işgücü piyasasına erişimin kısıtlanabilmesi imkanına rağmen, sekiz Orta ve Doğru Avrupa ülkesine (Çekya, Estonya, Macaristan, Letonya, Litvanya, Polonya, Slovakya ve Slovenya), istisnasız BK işgücü piyasasına doğrudan erişim imkanı sağlayan üç ülkeden biridir. ${ }^{45}$ Brexit öncesi döneme bakıldığında, 2015'te BK'da çoğunluğu Polonya, Çekya, Estonya, Macaristan, Letonya, Litvanya, Slovakya ve Slovenya'dan gelen işçi sayısı 1.2 milyonken, $14 \mathrm{AB}$ ülkesindeki toplam sayının sadece 800,000 civarında olduğu görülmektedir. 2019 itibariyle ise, BK'daki 29 milyonluk işgücü piyasasında 2,2 milyon $A B$ vatandaşı, 1,3 milyon da $A B$ vatandaşı olmayan göçmen işçi bulunmaktadır. ${ }^{46}$ İşsizlik oranlarına bakıldığında ise, bu oran BK vatandaşları için $\% 3,9, \mathrm{AB}$ vatandaşları için $\% 3,2$ ve üçüncü ülke vatandaşları için ise $\% 6,4$ 'tür. ${ }^{47}$

Brexit' in ilk etkilerinden biri, BK'ya AB ülkelerinden gelen işçi sayısının azalması olmuş̧ur. BK Ulusal İstatistik Ofisi'nin raporuna göre, 2019 itibari ile BK'ya iş amaçlı gelen $\mathrm{AB}$ vatandaşlarının sayısı 2004'ten bu yana en düşük seviyeye, inmiştir. ${ }^{48} \mathrm{BK}$ işgücü piyasasını incelendiğinde tarım, hizmet, yaşlı bakımı, sosyal hizmetler, teknoloji ve araştırma sektörlerinin genellikle $\mathrm{AB}$ üyesi ülkelerin vatandaşlarının istihdamına dayalı olduğu görülmektedir. Gıda sektöründe her üç çalışandan biri, inşaat sektörünün $\% 15$ 'i ve bilimsel araştırma çalışanlarının \%15'ini $A B$ vatandaşı işçiler oluşturmaktadır. ${ }^{49}$ Tarım alanında ise her 100 mevsimlik tarım işçisinin 99'u $\mathrm{AB}$ vatandaşıdır. ${ }^{50}$ Ülkedeki $\mathrm{AB}$ ülkesi vatandaşı olan işçiler arasında en

${ }^{45}$ Dennison ve Geddes, 1142.

46 BK Ulusal İstatistik Ofisi (ONS), "UK and Non-UK People in the Labour Market: November 2019," Erişim Tarihi: Mart 20 https://www.ons.gov.uk/employmentandlabourmarket/peopleinwork/employmentandemplo yeetypes/articles/ukandnonukpeopleinthelabourmarket/november2019

47 ibid

48 BK Ulusal İstatistik Ofisi (ONS), Migration Statistics Quarterly Report: February 2020, https://www.ons.gov.uk/peoplepopulationandcommunity/populationandmigration/internati onalmigration/bulletins/migrationstatisticsquarterlyreport/february2020\#main-points

49 Cinzia Rienzo, "Migrants in the UK labour market: an overview," The Migration Observatory, Temmuz 31, 2018, Erişim tarihi: Mart 2, 2020, https://migrationobservatory.ox.ac.uk/resources/briefings/migrants-in-the-uk-labourmarket-\%20an-overview/.

${ }^{50}$ BK Ulusal İstatistik Ofisi (ONS), "Labour in the Agriculture Industry, UK: February 2018," $\begin{array}{llll}\text { Erişim } & \text { Tarihi: } & \text { Mart } & \text { 2020, }\end{array}$ 
yüksek sayı Polonya uyruklu işçilerdir. Ancak son dönemlerde toplam 98,000 Polonya uyruklu kişi ülkelerine geri dönmüştür. ${ }^{51}$ Polonya'nın BK Büyükelçisi, ülkedeki yaklaşık 800,000 Polonya vatandaşına gönderdiği mektupla, onları ya BK'da uzun dönemli oturum başvurusuna ya da ekonomisi düzelen Polonya'ya geri dönmeye davet etmiştir. ${ }^{52}$ BK İçişleri Bakanı Priti Patel ise, AB vatandaşlarının ülkelerine olası geri dönüşü sonrası oluşabilecek işçi açığının, 16-64 yaş arası yaklaşık sekiz milyon ve ekonomiye katılmayan İngiliz vatandaşının işgücü piyasasına işverenler tarafından dahil edilmesiyle aşılabileceğini önermiştir. ${ }^{53}$ Oysa ki COVID-19 pandemisi BK'nın gıda, tarım ve sağlık hizmetlerinde göçmen işçilere olan kritik ihtiyaç ve bağımlılı̆̆ını ve bu alanlardaki işlerin yerel işgücü ile doldurulamayacağını açıkça göstermiştir. BK'nın AB'den ayrılmasında oldukça etkili olan göçmen karşıtlığı, BK ekonomisine göçmenlerin yük olduğu ve yerel nüfusun işini elinden aldıkları siyasi söylemi, pandemi sırasında BK'nın özellikle sağlık sistemlerinin ve yaşlı bakım hizmetlerinin büyük ölçüde yabancı doktor, hemşire ve sağlık personeline dayandığı gerçeği ile çelişmiştir. BK, 1 Ekim 2020'den önce çalışma vizesi bitecek olan Ulusal Sağlık Hizmeti (NHS) kapsamında çalışan 2800 yabancı doktor, hemşire, sağ lık çalışanı ve ailelerinin vizelerini ücretsiz olarak bir yıl daha uzatmıştır (Birleşik Krallı Hükümeti, 2020). ${ }^{54}$ BK'da yapılan bir araştırmaya katılanların \%77'si koronavirüse karşı hastanelerde ön safhalarda mücadele eden tüm yabancı doktor ve hemşirelere otomatik olarak BK vatandaşılı̆ııın verilmesi gerektiğini belirtmiştir. Çalışmaya katılan ve Brexit referandumunda ayrılma yönünde karar verenlerin \%72'si doktor ve hemşirelere, \%53'ü bakım hizmetleri çalışanlarına, \%40'ı market çalışanları ve tarım işçilerine, \%38'i ise kargo hizmeti çalışanlarına otomatik olarak BK vatandaşlığının verilmesi yönünde görüş bildirmiştir. ${ }^{55}$

https://www.ons.gov.uk/peoplepopulationandcommunity/populationandmigration/internati onalmigration/articles/labourintheagricultureindustry/2018-02-06.

51 Polonya İstatistik Ofisi, Erişim Tarihi: Mart 2, 2020, https://stat.gov.pl/en/.

52 BBC, "Brexit: Poles in UK should 'Consider' Returning, Polish Ambassador Says," Erişim tarihi: Mart 2, 2020, https://www.bbc.com/news/uk-49741175.

53 Robert Wright, "Priti Patel Dismisses Concerns over Immigration Reforms," Financial Times, Şubat 19, 2020, Erişim Tarihi, Mart 2, 2020, https://www.ft.com/content/9f8524ae52fb-11ea-8841-482eed0038b1.

${ }^{54}$ Birleşik Krallık Hükümeti, "NHS Frontline Workers Visas Extended So They Can Focus on Fighting Coronavirus," Erişim Tarihi: Nisan 30, 2020, https://www.gov.uk/government/news/nhs-frontline-workers-visas-extended-so-they-canfocus-on-fighting-coronavirus.

55 OpenDemocracy, Exclusive: Most Support UK Citizenship for Migrant Frontline Workers," Nisan 25, 2020, Erişim Tarihi: Mayis 30, 2020 , 
Diğer taraftan yine Brexit sürecinin önemli söylemlerinden biri olan BK'nın ucuz ve düşük nitelikli işçi göçüne olan ihtiyacını sonlandırarak özellikle sosyo-ekonomik olarak daha geride olan $\mathrm{AB}$ ülkelerinden gelen göçü durduracağı ifadelerine karşın, pandemi sırasında BK'nın tarım ve gıda sektöründe göçmen işçilere olan kaçınılmaz ihtiyaç ve bağımlılığı bir kez daha açıkça görülmüştür. Tarım sektöründe göçmen işçilere duyulan ivedi ihtiyaç nedeniyle, dünyada birçok ülkesınır esnekliklerini tarımsal faaliyetler özelinde uygulamak zorunda kalırken, BK da tarla ve meyve bahçelerinde ürün hasatlarının yapılabilmesi ve ürünlerin çürümemesi için sınırlar kapalıyken özel uçuşlarla Doğu Avrupa ülkelerinden mevsimlik tarım işçilerini BK'a taşımıştır. ${ }^{56}$ İngiltere'deki Üreticiler Derneği gıda krizinin önüne geçebilmek ve yerel işgücünü çekebilmek için "Pick for Britain" ve İngiltere Etik İş Sağlayıcıları Birliği'ne bağlı iş ve işçi bulma firmaları ise pandemi nedeniyle işsiz kalanları tarıma yönlendirmek için "Feed the Nation" kampanyalarını başlatmıştır. Ancak bu kampanyalar özellikle tarımda yerel nüfusun hem bu alanda çalışmak için yeterli niteliğe sahip olmadığını hem de tarımda çalışmaya çok ilgi duymadığını göstermiştir. Tarımda göçmen işçilerin olmaması durumunda, bu alandaki işçi açı̆̆ının yerel işgücü ile doldurulabilmesinin çok da gerçekçi bir yaklaşım olmadığı pandemi tecrübesiyle daha da net görülmüsşür.

Diğer taraftan, $\mathrm{BK}$ 'ya gelen $\mathrm{AB}$ vatandaşı olmayan göçmenlerin net göç sayısı 250,000 ile 2004'ten bu yana en yükssek sayıya ulaşmıştır. ${ }^{57} \mathrm{Bu}$ kişilerin büyük bölümü BK'ya eğitim amaçlı gelen öğrenci ve araştırmacılardan oluşmaktadır. ${ }^{58} 2019$ senesi, AB vatandaşı olmayanların BK'da üniversitelere burslu/sponsorlu vize başvurularının rekor düzeye eriştiği sene olarak raporlanmıştır. Aşağıdaki tablo, $\mathrm{BK}$ 'ya gelen $\mathrm{AB}$ vatandaşı olmayan kişilerin net göç oranının Brexit referandumu sonrası azalmadığını, bilakis, $A B$ vatandaşları BK' dan ayrlırken, üçüncü ülke vatandaşlarının net göç oranının arttığını göstermektedir.

https://www.opendemocracy.net/en/opendemocracyuk/exclusive-most-support-ukcitizenship-migrant-frontline-workers/.

56 BBC News Türkçe, "Koronavirüs: İngiltere'de Sebze ve Meyve Toplayacak Doğu Avrupalı İşçiler için Özel Uçuşlar Düzenleniyor,” Nisan 16, 2020, Erişim Tarihi: May1s 30, 2020, https://www.bbc.com/turkce/haberler-dunya-52303923.

${ }^{57}$ BK Ulusal İstatistik Ofisi, 2020.

58 ibid. 
Figür 1. Birleşik Krallık Net Göç (Aralık 2009-Eylül 2019), 1000 kişi

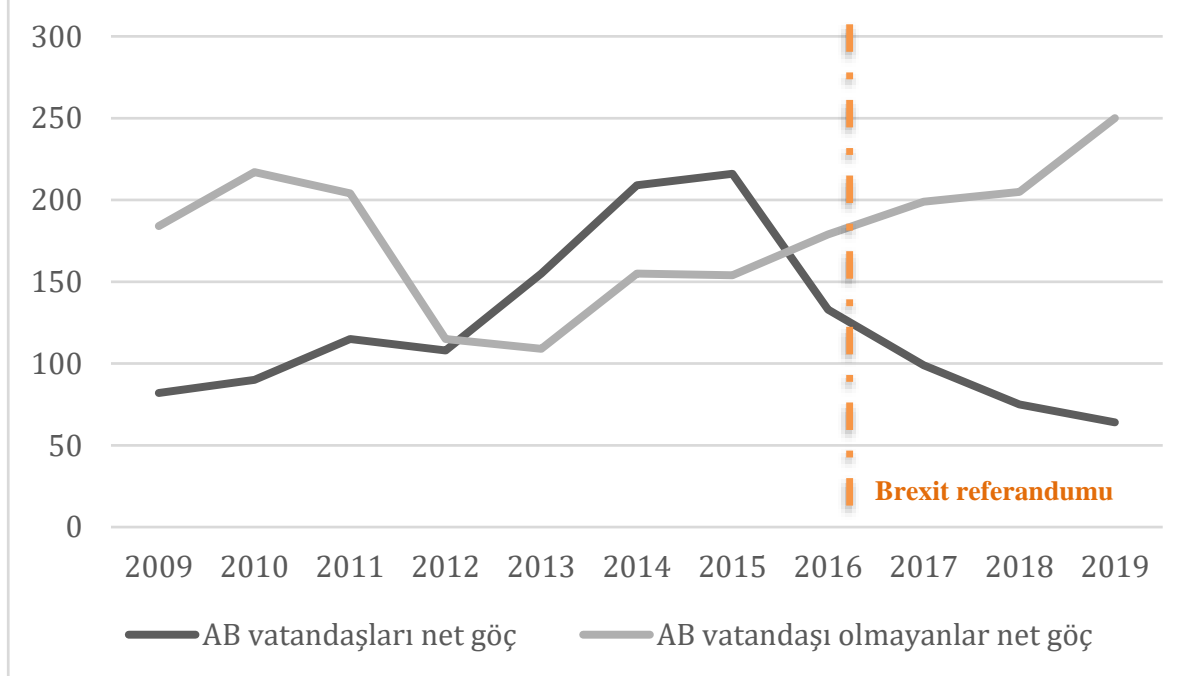

Kaynak: BK Ulusal İstatistik Ofisi verileri kullanılarak hazırlanmıştır ${ }^{59}$

Geçiş dönemi öncesinde $\mathrm{BK}$ veya $\mathrm{AB}$ 'de yerleşik bulunan vatandaşların kazanılmış haklarının 2004/38 sayılı Vatandaş Hakları Direktifi'ne uygun olarak korunması öngörülmüştür. $\mathrm{BK}$, Brexit öncesi ülkede yaşayan $\mathrm{AB}$ vatandaşlarının haklarını korumaya yönelik, $A B$ vatandaşlarının 30 Haziran 2021'e kadar oturma izni için başvurmaları zorunluğunu getirmiştir. Oturum izni için başvurmayan $\mathrm{AB}$ vatandaşları verilen süre sonunda ülkeden sınır dışı edilebilecektir. BK'da yaşayan $\mathrm{AB}$ vatandaşlarının "yerleşik statü”" (settled status) denilen kalıcı oturma iznini alabilmeleri için beş yıldır BK' da oturuyor olmaları gerekmektedir. ${ }^{60} \mathrm{Bu}$ süreyi dolduramayanlar ise süreli oturma ve çalışma izni anlamına gelen "yerleşik öncesi statü" (Pre Settled Status) alabilecektir. Düşük nitelikli işlerde çalışanlar içinse farklı bir süreç öngörülmüş ve bu kişilere oturum değil, sadece 2-3 yıllık geçici izinler verilmesi düşünülmüştür. Dolayısıyla serbest dolaşım konusu yüksek nitelik gerektiren işlerde çalışanlar ve öğrenciler için farklı ve nispeten daha kolay,

${ }^{59}$ Birleşik Krallı Ulusal İstatistik Ofisi (ONS), "Migration Statistics Quarterly Report: February 2020," Erişim Tarihi: Mart 2020, https://www.ons.gov.uk/peoplepopulationandcommunity/populationandmigration/internati onalmigration/bulletins/migrationstatisticsquarterlyreport/february 2020

${ }^{60}$ BK Hükümeti, “Apply to the EU Settlement Scheme (Settled and Pre-settled Status)," Erişim Tarihi: Mart 2, 2020, https://www.gov.uk/settled-status-eu-citizens-families 
düşük nitelik gerektiren işlerde çalışanşar içinse daha kısıtlayıcı süreçler öngörmektedir. ${ }^{61}$

Birleşik Krallık, 31 Aralık 2020'de serbest dolaşımın sona ermesiyle hem $\mathrm{AB}$ vatandaşları hem de $\mathrm{AB}$ dışı üçüncü ülkelerden gelen kişiler için aynı başvuru koşullarını içeren yeni bir "göçmenlik puan sistemi" (points based system) uygulayacağını ilan etmiştir. ${ }^{62}$ İçişleri Bakanı Priti Patel, yeni göçmenlik sisteminin dünyanın dört bir yanından en parlak ve en iyileri BK'ya çekerek ülkenin ekonomisini güçlendireceğini söylemiştir. ${ }^{63}$ Serbest dolaşım hakkı sonlandığında, BK'da çalışmak isteyen tüm AB vatandaşları yeni göçmenlik sistemine göre $\mathrm{AB}$ üyesi olmayan diğer üçüncü ülke vatandaşları gibi çalışma ve oturma izni almak zorunda kalacaktır. Brexit geçiş dönemi sonrasında, $\mathrm{BK}$ 'da çalışmak isteyen $\mathrm{AB}$ vatandaşlarının tıpkı diğer üçüncü ülke vatandaşları ile aynı statüde, eşit rekabet şartlarında, aynı vize ve oturum başvuru süreçlerine tabi olması, bu kişileri, serbest dolaşımdan hakkından "AB göçmenliği”" şeklinde ifade edilebilecek yeni bir statüye getirmektedir. $\mathrm{Bu}$ durum, $\mathrm{AB}$ vatandaşlarının ortak pazar kapsamında $\mathrm{BK}$ 'daki işgücü piyasasının ihtiyaç ve şartlarına göre daha çok emek piyasasının arz talep şartlarına göre şekillenen hareketliliğini, BK'nın daha seçici, kendi kontrolünde ve izin/onay temelli bir göç sistemi yaklaşımıyla düzenleyebilmesini sağlamaktadır.

1 Ocak 2021'de yürürlüğe girecek yeni göçmenlik sistemine göre, başvuru sahibinin İngilizce seviyesi, eğitim durumu, mesleği ve İngiltere'de sponsorluğa uygun bir kurumdan iş teklifi gibi unsurlar dikkate alınacaktır. Yapılacak değerlendirmede toplamda en az 70 puan alanların BK'ya göçmen olarak gelebilmesi mümkün olacaktır. Sponsorluk için gereken asgari yıllık brüt ücret 25 bin 600 sterlindir. Bu kriterler göz önüne alındığında göçmenlik başvurularında yüksek nitelikli, beyaz yakalı meslek sahibi kişilerin tercih edildiği, düşük vasıflı işçilerinse BK'ya gelişlerinin kısıtlanması yönünde bir yaklaşımın olduğu görülmektedir. Yapılan bir araştırmaya göre BK'da otel, restoran ve ulaşım gibi sektörlerde çalışmakta olan $\mathrm{AB}$ vatandaşlarının yaklaşık \%75'nin yeni göçmenlik kriterlerini sağlamakta zorlanacağı için BK'da çalışabilmesi mümkün olmayacaktır. ${ }^{64}$ Yeni göçmenlik sistemi, Brexit

${ }^{61}$ Owen vd., 2019

62 BK İçişleri Bakanlığ 1 , “The UK's Future Skills-based Immigration System,” The Stationery Office, (2018), Erişim Tarihi: Mart 2, 2020, www.gov.uk/government/publications/the-uksfuture-skills-based-immigration-system

${ }^{63}$ Birleşik Krallık Hükümeti, "UK Announces New Points-Based Immigration System, Şubat 19, 2020, Erişim Tarihi: Mart 2, 2020, https://www.gov.uk/government/news/uk-announcesnew-points-based-immigration-system

${ }^{64}$ The Institute for Public Policy Research (IPPR), "Vast Majority of EU Workers would be Barred from UK under Migration Advisory Committee Proposals," Ekim 9, 2018, Erişim 
yanlıları tarafından her ne kadar BK'ya gelen göçmen sayısını azaltacağı yönünde desteklense de, Avustralya, Kanada ve Yeni Zelanda örneklerinde de görüldüğü gibi puan sistemi nedeniyle $\mathrm{BK}$ 'ya gelen göçmen sayılarının azalmayacağı, ancak Brexit sonrasında oluşan belirsizlik döneminin yarattı̆̆ 1 ekonomik bozulma nedeniyle BK'ya göçün azalması daha muhtemeldir. ${ }^{65}$

Brexit geçiş dönemi sonunda, AB'de yaşayan BK vatandaşlarının da durumunun ne olacağı konusunda ise belirsizlik devam etmektedir. Süreçler karşı1ıklılık esasına göre düzenlenirse, $\mathrm{AB}$ 'de yaşayan $\mathrm{BK}$ vatandaşları için de zorlu bir süreç olması muhtemeldir. $\mathrm{AB}, \mathrm{BK}$ vatandaşları için tıpkı diğer üye olmayan ülke vatandaşlarına uyguladığ 1 Uzun Dönemli Oturum İzni Direktifi veya Mavi Kart Direktifi gibi mevzuatları BK vatandaşları için uygulayabilir. Bunun yanı sıra, üye devletler de kendi ulusal hukuklarından kaynaklanan birçok kısıtlayıcı önlemi gündeme getirebilir. Diğer taraftan, BK vatandaşlarının ilerleyen zamanlarda ülkelerine dönmeyi istemeleri durumunda, BK vatandaşı olmayan eşlerinin veya aile üyelerinin durumlarının da nasıl düzenleneceğine dair endişeler bulunmaktadır. $\mathrm{Bu}$ alandaki belirsizlik ancak BK'nın AB ile ilişkisinin nasıl bir modelde gelişeceğine dair anlaşma sağlandığında düzenlenebilecektir. Avrupa Ekonomik Alanı, İsviçre modeli, Norveç Modeli, Kanada modeli gibi örnekler yeni iliş̧inin yapısına dair tartışmalardan birkaçını oluşturmaktadır.

\section{Sonuç}

Göç konusu, Brexit sürecinde BK halkına siyasi, ekonomik ve kültürel bir güvenlik tehdidi olarak sunulmuş, kamuoyundaki kimlik ve ulusal egemenliğe dair endişeleri tetiklemiş ve nihayetinde resmi olarak 2020'de BK'nın AB'den ayrılması ile sonuçlanan sürecin en etkili unsurlarından biri olmuştur. BK, AB'nin göç, sınır ve sığınma politikalarına opt-out imkanıyla büyük ölçüde katılmıyor olsa da, Birlik’ten ayrılma yanlıları kampanyalarında sınırların kontrolü ve ulusal egemenliğin geri alınması söylemini etkili şekilde kullanmışlardır. AB karşıtı UKIP tarafından kimlik siyasetinin bir parçası olarak araçsallaştırılan göç konusu, referandum sürecinde daha da siyasallaşmış ve BK'nin Birlikten ayrılması sürecinin başat nedeni olmuştur. Oysa ki, Brexit'in gerçekleşmesi sonrasında, BK ve AB arasında göç özelinde

Tarihi: Mart 2, 2020, https://www.ippr.org/news-and-media/press-releases/vast-majority-ofeu-workers-would-be-barred-from-uk-under-migration-advisory-committee-proposalsfinds-ippr

${ }^{65}$ Matteo Gravoglia, "What Brexit Means for Migration Policy,” Brookings Institute, Eylül 26, 2016. Erişim Tarihi: Mart 2, 2020 https://www.brookings.edu/blog/order-fromchaos/2016/09/26/what-brexit-means-for-migration-policy/ 
sınır yönetimi, sığınma ve üçüncü ülke vatandaşlarına karşı göç politikalarında eskisine göre BK'ya daha fazla yarar sağlayacak büyük ve önemli değişiklikler beklenmemektedir. Keza, BK'nın göçün güvenlikleştirilmesi, göçmenlerin Avrupa'ya erişimlerinin kısıtlanması ve güvenlik bilgilerinin paylaşılması gibi konularda $\mathrm{AB}$ politikalarına katılım gösterdiği ancak göçmen hakları, aile birleşimi, mültecilerin kabülü gibi konularda $\mathrm{AB}$ politikalarının dışında kaldığı Brexit öncesinde de bilinen bir gerçektir. Diğer taraftan, Brexit kampanyasındaki BK'ya artan göçü kısıtlamak söylemine yönelik olarak da, son dört yılda $A B$ vatandaşlarının $\mathrm{BK}$ 'dan ayrıldığı ancak $\mathrm{AB}$ vatandaşı olmayanların net göçünde ülkeye artış olduğu görülmektedir.

Brexit'in, göç politikalarına ilişkin en önemli etkisi, 1994'ten bu yana etkin şekilde işleyen ortak pazar ve işgücü piyasasında $A B$ ve $B K$ vatandaşlarının durumuna ilişkin olacaktır. Ortak pazarın serbest dolaşım hakkı kapsamında $\mathrm{AB}$ ülkelerinde çalışan yaklaşık bir milyon İngiliz vatandaşı ile $B K$ 'da çalışan yaklaşı 3,5 milyondan fazla $A B$ vatandaşının hem $\mathrm{BK}$ hem de $\mathrm{AB}$ ekonomisine sundukları kazanımlar açıtır. Ancak, 31 Aralık 2021 tarihinde serbest dolaşımın son bulmasıyla $A B$ ve $B K$ vatandaşlarının ve ailelerinin durumlarının nasıl düzenleneceği, işgücü piyasasında yaşanacak yeni hareketlenmenin ekonomiye ve kültürel yapıya etkilerinin ne olacağını kestirmek yeni ilişkinin çerçevesi henüz netleşmediği için zor ve karmaşıktır. Brexit sonrası döneme ilişkin BK, puan temelli yeni bir göçmenlik sistemini uygulayacağını duyurmuştur. Yeni puan sistemi, AB vatandaşlarını $A B$ üyesi olmayan üçüncü ülke vatandaşları ile aynı statüye getirmekte ayrıca koyduğu yeni koşullarla yüksek nitelikli işlerde çalışabilecek göçmenleri önceliklendirirken, daha düşük vasıflı işlerde çalışabilecek göçmen işçilerin BK'da kalışlarını ve BK'ya gelişlerini kısıtlamaktadır. Özetle, Brexit sonrası yeni dönemde, izin temelli göçmen sistemi AB'nin hak temelli serbest dolaşım sisteminin yerini almakta, $A B$ vatandaşlarını da "AB göçmenleri” konumuna dönüştürmektedir. ${ }^{66}$ Oysa ki COVID-19 pandemi sürecinde açıkça görüldüğü gibi, göçmen işçilerin niteliğinden öte önemli olan çalıştıkları alanların gıda, sağlık, tarım gibi "temel alanlar" olması gerçeğidir. Bu noktada, nitelikli/niteliksiz göçmen işgücü ayrımının değil, göçün toplumların karşılıklı ihtiyaçlarını tamamlayan kalkınmayı destekleyen boyutunun da olduğunun anlaşılabilmesi önemlidir. Bir diğer ifadeyle, BK'nın yeni göçmenlik politikasını "nitelikli ve niteliksiz işgücü" üzerine planlamış olması, günümüz şartlarında kimi çalışma alanları için ihtiyaç duyulan ve politikaların farklılaştığı "temel işçiler" kavramına ilişkin gelişmelerin de gerisinde kalmaktadır.

${ }^{66}$ Dennison ve Geddes, 1147. 
Brexit, Avrupa bütünleşme süreci için de önemli deneyimler sunmaktadır. BK'nın Birlik'ten ayrılması, Avrupa bütünleşmesinin yeni bir modele evrilerek gelişmesini sağlayacak bir tecrübe olabileceği gibi, diğer yandan da, bazı AB üyelerinin Birliğe olan bağlılığını zayıflatabilecek ve bütünleşme sürecine ilişkin domino etkisi yaratabilecek riskleri de içermektedir. Yeni-işlevselciler, Birliğin daha önce yaşadığ 1 boş sandalye krizi (1965), genişleme krizi, ${ }^{67}$ Avro krizi, gibi birçok zorlu süreçten bütünleşmeyi güçlendirerek çıktığını ifade etse de, Brexit'in önceki krizler gibi olumlu bir etki yaratamayacağını savunanlar da vardır. ${ }^{68}$ Hatta, Brexit'in Avrupa bütünleşme tarihinde dağılmaya referans teşkil eden bir kırılma olabileceği de tartışılmaktadır. ${ }^{69} \mathrm{AB}$ bugün birçok üye ülkede yükselen radikal sağ partiler, artan göç, sınırlarda yaşanan kriz, kurucu insani değerlerin erozyonu gibi farklı birçok sorunla karşı karşıyayken, Brexit deneyiminin spekülasyonlara açık olası etkilerini tahmin etmek oldukça zordur. Her hâlükârda Brexit, belirsizliğin hâkim olduğu AB'nin kurumsal geleceği tartışmalarında yeni bir ilişki modeline ve kapsamlı bir reform sürecine ihtiyaç duyulduğunu açıkça ortaya koymaktadır. Bu bağlamda, BK'nın AB dışında nasıl bir performans göstereceği, bu statünün BK'ya getireceği olumlu ve olumsuz gelişmeler, bu gelişmelerin diğer $\mathrm{AB}$ üyelerince nasıl algılanacağ 1 ve AB'nin ortak sorunlara karşı üye ülkelere sunacağı etkin çözümler, Brexit'in AB'nin geleceğini hangi yönde etkileyeceğini daha net belirleyecektir. Ancak kesin olan bir konu vardır ki, bütünleşme sürecinin ilerleyebilmesi için son zamanlarda daha çok tartışılan alternatif farklılaştırılmış entegrasyon modelinin, BK örneğinde olduğu gibi kimlik, yükselen radikal săg partiler ve referandum süreçleri gibi etkenlerle bir araya geldiğinde tamamen ayrılma veya dağılmayı da getirebileceği gerçeğidir.

${ }^{67}$ George Ross, The European Union and Its Crises. Through the Eyes of the Brussels Elite. (London: Palgrave Macmillan, 2011).

${ }^{68}$ Sabine Saurugger, Theoretical approaches to European integration. (Basingstoke: Palgrave Macmillan, 2013).

69 Thierry ve Lequesne, 541 


\section{Kaynakça}

Akses, Selen, Emre Ataç, Ahmet Ceran, Sema Çapanoğlu, Çisel İleri, İlge Kıvılcım, Çiğdem Nas, Deniz Servantie ve Yeliz Şahin Britanya Referandumu ve Sonrasi: AB Entegrasyon Sürecinin Geleceği ve Türkiye. İstanbul: İktisadi Kalkınma Vakfı Yayınları, 2016. Erişim Tarihi: Mart, 2, 2020. https://www.ikv.org.tr/images/files/IKV_Brexit_Yayin\%20no\%20284(1).pdf

Alan, Gülsüm. “AB'den İngiltere’ye Özel Statü.” Euronews, Şubat 20, 2016. Erişim Tarihi: Mart 2, 2020. https://tr.euronews.com/2016/02/20/ab-den-ingiltereyeozel-statu

Avrupa Komisyonu, "EURODAC 2020." Erişim Tarihi: Mart 2, 2020, https://ec.europa.eu/knowledge4policy/dataset/ds00008_en

Avrupa Komisyonu, "Standart Eurobarometer 85." Mayıs 2016. Erişim Tarihi: Mart 2 2020. https://ec.europa.eu/commfrontoffice/publicopinion/index.cfm/ Survey/getSurveyDetail/instruments/STANDARD/yearFrom/1974/yearTo/201 6/surveyKy/2130

Avrupa Komisyonu Eurostat, "Asylum and first time asylum applicants by citizenship, age and sex." Erişim Tarihi: Mart 2, 2020, http://appsso.eurostat.ec.europa.eu/nui/setupDownloads.do.

BBC News. "EU Referendum: Nigel Farage Tells Leave Campaigners to Focus on Migration.” Nisan 29, 2016. Erişim Tarihi: Mart 2, 2020. https://www.bbc.com/news/uk-politics-eu-referendum-36167329

BBC News. "Brexit: Poles in UK should 'Consider' Returning, Polish Ambassador Says.” Eylül 18, 2019. Erişim tarihi: Mart 2, 2020, https://www.bbc.com/news/uk-49741175.

BBC News Türkçe. "Koronavirüs: İngiltere'de Sebze ve Meyve Toplayacak Doğu Avrupalı İşçiler için Özel Uçuşlar Düzenleniyor.” Nisan 16, 2020, Erişim tarihi: Mayis 30, 2020, https://www.bbc.com/turkce/haberler-dunya-52303923

Birleşik Krallık Hükümeti. "Review of the Balance of Competences between the UK and the EU: The Single Market.” (Londra: Temmuz 2013). Erişim Tarihi: Mart 3 , 2020 , https://assets.publishing.service.gov.uk/government/uploads/system/uploads/att achment_data/file/227069/2901084_SingleMarket_acc.pdf

Birleşik Krallık Hükümeti. "UK Announces New Points-Based Immigration System." Şubat 19, 2020. Erişim Tarihi: Mart 2, 2020, https://www.gov.uk/government/news/uk-announces-new-points-basedimmigration-system

Birleşik Krallık Hükümeti. "Apply to the EU Settlement Scheme (Settled and Presettled Status).” Erişim Tarihi: Mart 2, 2020, https://www.gov.uk/settled-statuseu-citizens-families

Birleşik Krallık Hükümeti. "NHS Frontline Workers Visas Extended So They Can Focus on Fighting Coronavirus.” Mart 31, 2020. Erişim Tarihi: Nisan 30, 2020, 
https://www.gov.uk/government/news/nhs-frontline-workers-visas-extendedso-they-can-focus-on-fighting-coronavirus

Birleşik Krallık İçişleri Bakanlığı. "The UK's Future Skills-based Immigration System.” The Stationery Office, (2018). Erişim Tarihi: Mart 2, 2020, www.gov.uk/government/publications/the-uks-future-skills-basedimmigration-system

Birleşik Krallık Parlementosu Lordlar Kamarası AB Komitesi. "Brexit: Refugee Protection and Asylum Policy." 48th Report of Session 2017-2019, Ekim 11, 2019. Erişim Tarihi: Mart 2020. https://publications.parliament.uk/pa/ld201719/1dselect/ldeucom/428/428.pdf.

Birleşik Krallık Ulusal İstatistik Ofisi (Office for National Statistics/ONS), "UK Population by Nationality (July 2018- June 2019).” Erişim Tarihi: Mart 2, 2020. https://www.ons.gov.uk/peoplepopulationandcommunity/populationandmigrati on/internationalmigration/bulletins/ukpopulationbycountryofbirthandnationalit y/july2018tojune2019

Birleşik Krallı Ulusal İstatistik Ofisi (Office for National Statistics/ONS), "Migration Statistics Quarterly Report: February 2020." Erişim Tarihi: Mart 2, 2020 .

https://www.ons.gov.uk/peoplepopulationandcommunity/populationandmigration/in ternationalmigration/bulletins/migrationstatisticsquarterlyreport/february 2020

Birleşik Krallık Ulusal İstatistik Ofisi (Office for National Statistics/ONS), "The Electoral Commission, EU Referendum Results by Region: North East.” Erişim Tarihi: Mart 2, 2020.https://www.electoralcommission.org.uk/who-we-are-andwhat-we-do/elections-and-referendums/past-elections-and-referendums/eureferendum/results-and-turnout-eu-referendum/eu-referendum-results-regionnorth-east;

Birleşik Krallık Ulusal İstatistik Ofisi (Office for National Statistics/ONS), "UK and Non-UK People in the Labour Market: November 2019." Erişim Tarihi: Mart 2, 2020, https://www.ons.gov.uk/employmentandlabourmarket/peopleinwork/employm entandemployeetypes/articles/ukandnonukpeopleinthelabourmarket/november2 019

Birleşik Krallık Ulusal İstatistik Ofisi (Office for National Statistics/ONS), "Labour in the Agriculture Industry, UK: February 2018.” Erişim Tarihi: Mart 2, 2020, https://www.ons.gov.uk/peoplepopulationandcommunity/populationandmigrati on/internationalmigration/articles/labourintheagricultureindustry/2018-02-06

Cappelen, Cornelius ve Yvette Peters. "Diversity and Welfare State Legitimacy in Europe: The Challenge of Intra-EU Migration." Journal of European Public Policy 25, 9 (2018): 1336-1356.

Clarke, Harold D., Matthew Goodwin, Paul Whiteley. "Why Britain Voted for Brexit: An Individual-Level Analysis of the 2016 Referendum Vote.” Parliamentary Affairs 70, 3 (Temmuz 2017): 439-464. 
Chopin, Thierry ve Christian Lequesne. "Differentiation as a Double-Edged Sword: Member States' Practices and Brexit." International Affairs 92, 3 (2016): 531545.

Costello, Cathryn ve Emily Hancox. The UK, EU Citizenship and Free Movement of Persons. UK: University of Oxford, 2014. Erişim Tarihi: Mart 2, 2020. https://migrationobservatory.ox.ac.uk/wpcontent/uploads/2016/04/PolicyPrimer-UK_EU_Asylum_Law.pdf

Dennison, James ve Andrew Geddes. "Brexit and the Perils of Europeanised Migration." Journal of European Public Policy 25, 8 (2018), 1137-1153.

Dyson, K., Sepos, A. "Differentiation As A Design Principle and As A Tool in The Political Management of European Integration." içinde Which Europe? The Politics of Differentiated Integration, editörler Kenneth Dyson, Angelos Sepos, A, 3-23. Basingstoke: Palgrave Macmillan, 2010.

Duttle, Thomas, Katharina Holzinger, Thomas Malang, Thomas Schaubli, Frank Schimmelfennig ve Thomas Winzen. "Opting out from EU Legislation: The Differentiation of Secondary Law." Journal of European Public Policy 24, no 3 (2017): 406-428. Erişim Tarihi: Mart 2, 2020. doi: 10.1080/13501763.2016.1149206.

Goodwin, Matthew ve Caitlin Milazzo. UKIP: Inside the Campaign to Redraw the Map of British Politics. Oxford: Oxford University Press, 2015.

Gravoglia, Matteo. "What Brexit Means for Migration Policy." Brookings Institute, Eylül 26, 2016. Erişim Tarihi: Mart 2, 2020 https://www.brookings.edu/blog/order-from-chaos/2016/09/26/what-brexitmeans-for-migration-policy/

Henderson, Alisa, Charlie Jeffery, Dan Wincott ve Richard Wyn Jones. "How Brexit was Made in England." The British Journal of Politics and International Relations 19, no 4 (2017): 631-646.

Holzinger, Katharina ve Tosun, Jale. "Why Differentiated Integration Is Such A Common Practice In Europe: A Rational Explanation." Journal of Theoretical Politics 31, no 4 (2019): 642-659.

Holzinger, Katharina ve Frank Schimmelfennig. "Differentiated Integration In the European Union: Many Concepts, Sparse Theory, Few Data." Journal of European Public Policy 19, no 2 (2012):292-305.

Hooghe, Leisbet ve Gary Marks. "A Postfunctionalist Theory of European Integration: From Permissive Consensus to Constraining Dissensus.", British Journal of Political Science 39 (2009): 1-23. Erişim Tarihi: Mart 2, 2020. doi: $10.1017 /$ S0007123408000409.

Koenig, Nicole. "A Differentiated View of Differentiated Integration,." Jacques Delors Institute Policy Papers 140, (23 Temmuz 2015). Erişim Tarihi: Mart 2, $2020 . \quad$ https://institutdelors.eu/en/publications/a-differentiated-view-ofdifferentiated-integration/ 
Kutlay, Mustafa. "Brexit Sonrası İngiltere ve AB Bütünleşmesinin Geleceği.” Liberal Perspektif: Analiz 4, (Ocak 2017): 9.

Lavenex, Sandra. "Concentric Circles of Flexible 'EUropean' Integration: A Typology of EU External Governance Relations.” Comparative European Politics 9, no 4-5 (2011): 372-393.

Leruth, Benjamin ve Christopher Lord. "Differentiated Integration in the European Union: A Concept, a Process, a System or a Theory?" Journal of European Public Policy 22, no 6 (2015): 754-763.

Leruth, Benjamin, Stefan Ganzle ve Jarle Trondal. "Differentiated Integration and Disintegration in the EU After Brexit: Risks versus Opportunities." Journal of Common Market Studies 57, no 6 (2019): 1386

Leuffen, Dirk., Berthold Rittberger ve Frank Schimmelfennig. Differentiated Integration. Explaining Variation in the European Union, Basingstoke: Palgrave, 2013.

McTague, Tom. "Theresa May Reveals new UK Immigration System." Politico, Ekim 2, 2018. Erişim Tarihi: Mart 2, 2020 www.politico.eu/article/theresa-mayunveils-new-uk-immigration-system

OpenDemocracy. "Exclusive: Most Support UK Citizenship for Migrant Frontline Workers." Nisan 25, 2020. Erişim Tarihi: Mayıs 30, 2020, https:/www.opendemocracy.net/en/opendemocracyuk/exclusive-most-supportuk-citizenship-migrant-frontline-workers/

Owen, Joe, Maddy Thimont Jack, Adela Lacobov ve Elliot Christensen, "Managing Migration After Brexit.” Institute for Government, (Mart 2019). Erişim Tarihi: Mart 2, 2020, https://www.instituteforgovernment.org.uk/sites/default/files/publications/IfGMigration-After-Brexit_4.pdf

Öniş, Ziya ve Mustafa Kutlay. "Ekonomik Bütünleşme/Siyasal Parçalanmışlık Paradoksu: Avro Krizi ve Avrupa Birliği’nin Geleceği.” Uluslararası İlişkiler 9, say1 33 (2012): 3-22.

Polonya İstatistik Ofisi, Erişim Tarihi: Mart 2, 2020, https://stat.gov.pl/en/

Rienzo, Cinzia. "Migrants in the UK labour market: an overview." The Migration Observatory, Temmuz 31, 2018, Erişim tarihi: Mart 2, 2020, https://migrationobservatory.ox.ac.uk/resources/briefings/migrants-in-the-uklabour-market-\%20an-overview/.

Ross, George. The European Union and Its Crises. Through the Eyes of the Brussels Elite. London: Palgrave Macmillan, 2011.

RT, “Turkey's Bid for EU Membership Bolsters Case for Brexit- Farage.” Erişim Tarihi: Mart 2, 2020. https://www.rt.com/uk/335012-turkey-eu-membershipfarage/ 
Saurugger, Sabine. Theoretical approaches to European integration. Basingstoke: Palgrave Macmillan, 2013.

Schimmelfennig, Frank. "Brexit: differentiated disintegration in the European Union.” Journal of European Public Policy 25, no 8, (2018): 1154-1173.

Schimmelfennig, Frank. "Good governance and differentiated integration. Graded membership in the European Union." European Journal of Political Research 55, no 4 (2016): 795.

Schimmelfennig, Frank., Dirk Leuffen ve Berthold Rittberger, "The European Union as a system of differentiated integration: interdependence, politicization and differentiation" Journal of European Public Policy, 22: no 6, (2015): 764-782.

Schneider, Christina, J. Conflict, Negotiation and European Union Enlargement. Cambridge: Cambridge University Press, 2009.

Somerville, Will. "Brexit: The Role of Migration in the Upcoming EU Referendum." Migration Policy Institute, Mayıs 4, 2016. Erişim Tarihi: Mart 2, 2020 https://www.migrationpolicy.org/article/brexit-role-migration-upcoming-eureferendum.

Stubb, Alexander C-G. "A Categorization of Differentiated Integration." Journal of Common Market Studies 34, no 2 (1996): 283-295.

The Institute for Public Policy Research (IPPR). "Vast Majority of EU Workers would be Barred from UK under Migration Advisory Committee Proposals." Ekim 9, 2018. Erişim Tarihi: Mart 2, 2020, https://www.ippr.org/news-and-media/pressreleases/vast-majority-of-eu-workers-would-be-barred-from-uk-undermigration-advisory-committee-proposals-finds-ippr

Turhan, Ebru. "Thinking out of The Accession Box: The Potential and Limitations of Internal and External Differentiated Integration between Turkey and the EU." CIFE Policy Paper, no 58, (2017):1-8. Erişim Tarihi: Mart 2, 2020. https://www.cife.eu/Ressources/FCK/files/publications/policy\%20paper/CIFE Policy_Paper_58_Thinking_out_of_The_Accession_Box_EU_Turkey_Ebru_T urhan_2017_1.pdf

Walker, Neil. "Sovereignty and Differentiated Integration in the European Union." European Law Journal 4, no 4 (1998): 355-88.

Wallace, Hellen. Flexibility: A Tool of Integration or a Restraint on Disintegration? Oxford: Oxford University Press, 2000.

Wright, Robert. "Priti Patel Dismisses Concerns over Immigration Reforms." Financial Times, Şubat 19, 2020. Erişim Tarihi, Mart 2, 2020, https://www.ft.com/content/9f8524ae-52fb-11ea-8841-482eed0038b1 